\title{
Blended Learning in Mathematical Statistics I
}

\author{
Hazmira Yozza ${ }^{1}$, Yudiantri Asdi², Izzati Rahmi $\mathrm{HG}^{3}$ \\ \{hazmirayozza@sci.unand.ac.id ${ }^{1}$, yudiantri asdi@gmail.com², izzatirahmihg@sci.unand.ac.id $\left.{ }^{3}\right\}$ \\ ${ }^{1,2,3}$ Department of Mathematics, Faculty of Mathematics and Natural Sciences, Universitas Andalas, \\ Padang, Indonesia
}

\begin{abstract}
In this research, blended learning strategy using face to face driver model was applied in Mathematical Statistics I. Using this model, traditional learning remains the main approach in delivering lecture materials, while online learning functions as the supplement for the previous approach. The aims are to improve learning outcomes and provide a different learning experience for students. This research is an observational research. It is found that this approach increases students' learning outcome. Students also found that the online learning introduced was useful to enhance their understanding on the materials being studied.
\end{abstract}

Keywords: Blended Learning, face-to-face driver model, Mathematical Statistics I, learning outcome.

\section{Introduction}

Since the beginning of the 21 st century, there has been a paradigm shift in learning where the learning process is directed to encourage students to find out knowledge from various sources. Supported by the development of learning supporting technology, learning models a develop from traditional (face to face) towards electronic learning (E-Learning).

E-learning is a learning model that is carried out with the use of technological devices to facilitate the learning process. E-learning provides an opportunity for students to learn independently without being limited by space and time and holds control over learning success. In fact, the e-learning strategy cannot completely replace the face-to-face learning process. Lack of interaction between lecturers and students on e-learning can inhibit the formation of values in the learning process. With this approach, less motivated students, students which has no interest in modern technology or the ones which do not have adequate technological devices and internet access will tend to fail.

Blended Learning is the answer to the weaknesses of face-to-face learning and online learning. This learning approach is a combination of traditional and online learning. Blended learning is a suitable framework in higher education [1]. Various blended learning strategies have been developed and face-to-face driver model is one of them. With this model, learning is still carried out face-to-face, but teaching material is sent by teachers online

Mathematical Statistics I is a compulsory course for $4^{\text {th }}$ term students of Department of Mathematics of Andalas University. This course studies how to apply mathematical principles to statistics and provides theoritical foundation for studying and developing various statistical 
methods used to analyze data. Before, Mathematical Stattistics I learning process is conducted using traditional (face-to-face) strategy.

The obstacle faced in this course is the amount of teaching material that must be completed at one semerter. Therefore, this learning approach should be improved that can enchance student learning outcome. One strategy that can be used is to implement blended learning model. This article will discuss the design and implementation of blended learning strategy in Mathematical Statistics I and its impact on students' learning achievement and student participation on learning processes.

Technological developments and educational paradigm shifts have changed the learning strategy from traditional learning (face-to-face) to electronic learning that utilizes technology to facilitate the learning process. Some universities are trying to apply the concept of full elearning. From the Report of Online Learning Study in Higher Education in Indonesia in 2017 conducted by the Ministry of Research and Technology in 2017, only 382 (around 40\%) universities in Indonesia have conducted online learning, and this number still needs to be increased.

The advantage of e-learning is that it provides flexibility in choosing the time and place to access lessons, allowing people to learn without being limited by space and time, since access is available anytime and anywhere throughout the world [2]. The disadvantage is the lack of interaction between lecturer and student and among students that will slow down the formation of values in the learning process. In addition, this approach tends to be less successful if students have low learning motivation, are not interested in technology and do not have adequate internet equipment and facilities to participate in this learning. In Indonesia, which still refers to the academic regulatory system, face-to-face learning is still required, so full e-learning approach cannot replace conventional learning.

Blended learning is an opportunity to integrate the innovative and technological advances offered by online learning with the interaction and participation offered in the best of traditional learning[3]. Bersin [4]defines blended learningas the combination of different training"media" (technologies, activities, and types of events) to create an optimum training program for a specific audience. The term "blended" means that traditional instructor-led training is being supplemented with other electronic formats. In the context of this book, blended learningprograms use many different forms of elearning, perhaps complemented with instructor-led training and other live formats.

According to Thorne [3], blended learning is the most natural and logical evolution of the learning agenda. It is a way to complement face-to-face classes with web-based materials learning [5],[6], but can not replace it [6]. The main aspects of teaching and learning are student's own experiences of the process [7]. Blended Learning is a suitable framework to be applied in higher education [1]. Graham [8] danDziuban [9] showed that blended learning strategy helps students to learn independently, shifts teacher center paradigm toward student center paradigm and improve the achievement of learning outcome.

According to Graham [8], in blended learning, there is no standard composition between face-to-face learning and online learning. The composition commonly used is $50: 50(50 \%$ is used for face-to-face learning and 50\% for online learning). Other compositions are 75:25 or 25:75 [10].Various blended learning strategy have been developed i.e face-to-face driver model, rotation model, the flex model, self blend modeland enriched virtual model. 


\section{Methods}

The population of this study were all students who took Mathematical Statistics I course in academic year 2018/2019. All of the population members are participated in this study. This ia an observational research. Learning strategy developed is face-to-face driver blended learning model. In this research, online learning is implemented using supporting media, namely laptops/computers/smartphone devices, whatsapps applications, learning videos and Andalas University's ilearning portal. The stages in the development of blended learning in Mathematics Statistics I are as follows :

1. Need analysis; This stage aims to explore the difficulties of students in the learning process, the needs of students towards innovative learning models and learning facilities that have been owned by students associated with learning technology that will be developed.

2. Design blended learning model based on need analysis

3. Developmentof all learning media need, test it and improve it if there are potential obstacles in its implementation.

4. Implementation of developed blended learning strategy

5. Evaluation; This stage is conducted to evaluate the success of learning strategy developed. Indicators used are the distribution of students " final grade and students participation in online learning processes.

\section{Results and Discussion}

Now, we will describe the learning strategy that is developed in this study and discuss itsimpact to students performance and participation in learning process.

\subsection{The Development of Learning Strategy}

Blended learning strategy used in this study is a face-to-face driver model. In this learning model, face-to-face remains the main technique used in the teaching process, while online technology implemented is used as a complement. The face-to-face learning is a combination of Teacher-Centered Learning (TCL) and Student-centered learning (SCL) approach. Most of the material is given through the TCL approach andthe rest is through SCL jigsaw approach

In this study, online learning is implemented to support face-to-face learning. Online learning is a prerequisite for the proper implementation of this face-to-face activity. For students, online learning is a pre-learning activity by studying videos related to the material to be taught, through Ilearn or through the whatsapp application. With this video, it is expected that students will be better prepared to start learning activities. In addition, before lecture activities begin, a pre-test related to the material discussed in the video is held. The learning videos are freely accessed by students, so they can be learned any time they need an understanding of a learning material. The video is also very useful for students who do not attend the lectures.

In addition, online learning will also be designed as a post-learning activity with the aim of deepening understanding and broadening student knowledge about the learning material that has been provided. The approach is to provide a discussion forum for students which is carried out through ilearn portal and whatsapp. This forum is guided directly by lecturers. 


\subsection{Students Participation in Online Learning Processes}

In this research, online learning is carried out through Andalas University's Ilearning facilities and the whatsapp application. All learning videos and other teaching materials are provided through both channels so that they can be easily accessed and studied by students. The two channels are also used to inform and collect assignments and as a means of discussion between lecturers and students.

Table 4.1 Utilization of Learning Videos

\begin{tabular}{cllllll}
\hline \multirow{2}{*}{ No } & & \multicolumn{4}{c}{ Utilization* } \\
\cline { 3 - 7 } & & $\mathrm{A}$ & $\mathrm{B}$ & $\mathrm{C}$ & $\mathrm{D}$ & $\mathrm{Na}$ \\
\hline 1 & The Expected Value of Random Variable & 7 & 11 & 7 & 58 & 1 \\
2 & The properties of The expected Values & 7 & 8 & 8 & 60 & 1 \\
3 & Binomial Distribution & 8 & 12 & 21 & 41 & 2 \\
4 & Characteristics of Binomial Distribution & 10 & 12 & 17 & 42 & 3 \\
5 & Binomial Distribution (exercises) & 8 & 10 & 28 & 36 & 2 \\
6 & Negative Binomial Distribution & 10 & 12 & 20 & 40 & 2 \\
7 & Expected value of Negative Binomial Distribution & 12 & 14 & 23 & 33 & 2 \\
8 & Variance of Negative Binomial Distribution & 12 & 17 & 24 & 29 & 2 \\
9 & MGF of Negative Binomial Distribution & 13 & 16 & 22 & 31 & 2 \\
10 & Factorial MGF of Negative Binomial Distribution & 13 & 18 & 20 & 31 & 2 \\
11 & Continuous Uniform Distribution & 9 & 9 & 14 & 50 & 2 \\
12 & Expected value and Variance of Uniform Distribution & 10 & 13 & 20 & 39 & 2 \\
13 & MGF of Uniform Distribution & 12 & 11 & 20 & 39 & 2 \\
14 & CDF Method & 13 & 15 & 16 & 38 & 2 \\
15 & MGF Method & 13 & 15 & 21 & 33 & 2 \\
\hline$*$ & A= Didn't access the material; B=Partly-access; C=Fully-access, skimming & only; D $=$ Fully
\end{tabular}
access and learn; $\mathrm{Na}=$ Not answer

Student participation in online learning is assessed by their participation in accessing and studying the teaching material that is shared. In this study, 15 learning videos have been developed. Table 4.1 shows the degrees of student participation in utilizing the learning video. From Table 4.1 it is known that most students access the learning videos that have been uploaded and learn them. Generally, students access the teaching material before the lecture takes place (62\% of students), $17 \%$ of students access it after the lecture and $19 \%$ access it just before quiz or exam while $7 \%-13 \%$ of students did not access the material at all.

Online learning is also carried out by holding discussion forums. During this research period, five discussions were held. Compared to students' participation in accessing and studying teaching material, student participation to engage in discussion forums is not very good, as shown in the following table.

Table 4.2. Student participation in discussion forum

\begin{tabular}{ccc}
\hline Discussion No. & Channel & \% of participated-students \\
\hline 1 & Whatsapp & 93 \\
2 & Ilearning & 53 \\
3 & Ilearning & 43 \\
4 & Ilearning & 7 \\
5 & Ilearning & 6 \\
\hline
\end{tabular}


From this table it can be seen, for discussions conducted through WhatsApp, the level of student participation in discussions is very high. Ease of access through Whatsapp greatly supports student participation in these activities. However, for discussions conducted through i-learning, the level of student participation is very low. Some of the causes are (1) limited internet facilities, (2) Inadequate discussion time (3) Students still need time to understand the material to be discussed by themselves and (4) Prefer to study on their own.

\subsection{Final Grade Distribution}

The student's final score is in the 0-100 interval and is calculated based on the results assessment and process assessment and based on that score, student's final grade is determined. Figure 4.1 shows the distribution of students' final grade distribution presented in frequency histogram.

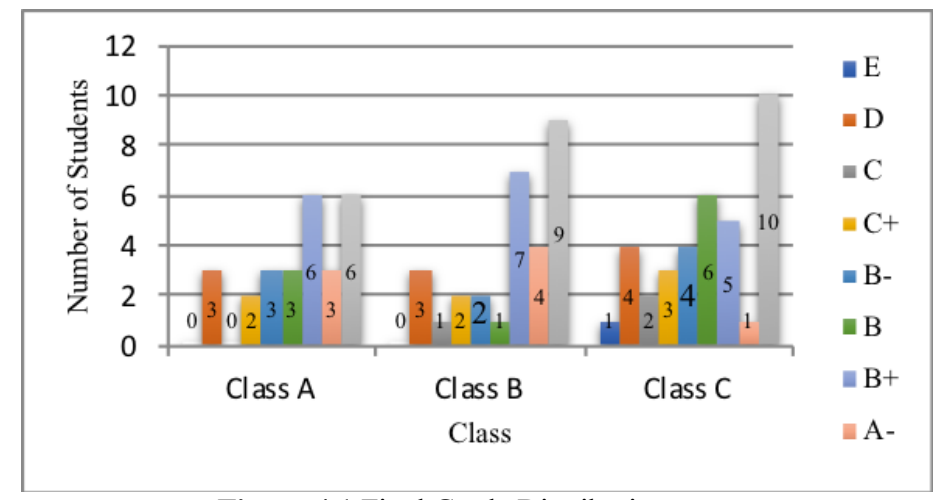

Figure 4.1 Final Grade Distribution

It is known from Figure 4.1 that the distribution of the final grades of Mathematical Statistics I in the three classes is quite good. The final grades of students in all three classes is left skewed, which means that the final grades of students are grouped on high grades. For the three classes, the highest frequency is in the grade A. There are no students who fail (get an E) in this course in all classes.

The final grades of Mathematics Statistics I courses in the 2017/2018 is then compared with 2018/2019 academic year, as shown in Figure 4.2.

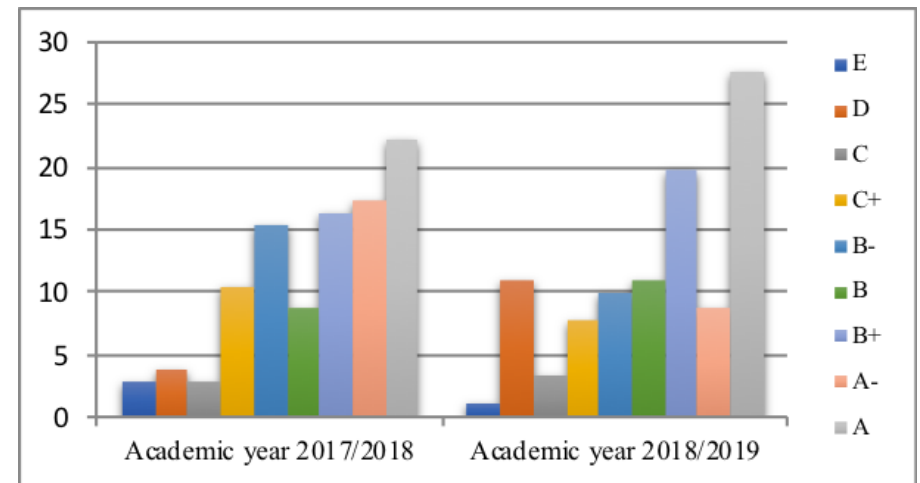

Figure 4.2 Comparisonof final grade distribution in academic year 2017/2018 and 2018/2019 
From this picture, it is known that the distribution of student grades in the 2017/2018 and $2017 / 2018$ academic year are left-skewed which means that students' final grade are accumulate on high grades. In this academic year, there was an increase in the percentage of students who received an A grade and a decrease in the percentage of students who got an E. However, the percentage of students who received a D grade also increase. Percentage of students who received a B- or less in this academic year was slightly reduced from $36 \%$ to $31 \%$.

\section{Conclusion}

In this research, blended learning technology was developed with a face-to-face driver approach. In this approach, all material is delivered face-to-face, online learning is used to support the face-to-face activities. Online learning is used as a pre-learning activity to prepare students in the learning process and post-learning activities to strengthen student understanding of the material being discussed. Online learning is done through the ilearning and Whatsapp. Both channels are used to upload learning videos and as a medium of discussion between students - lecturers and between students.

From the analysis conducted on the distribution of final grades, it is known that the distribution of student grades for the three classes are skew to the right, which means the student scores accumulate in high grades with the highest percentage of grades A. Compared to the previous learning strategy used,this learning strategy results better student learning outcomes.

The level of student participation is measured based on participation in accessing teaching material and discussion forum. It is known that the level of student participation in accessing and learning teaching material is high, which increase their understanding of the material taught in class. In contrast, student participation in discussion forums is low, which is caused by : the limited internet access, the time of discussion doesn't suit the student, student is not properly prepared for discussion and student study habit.

\section{Acknowledgments}

This paper is part of Research of Educational Development and Quality Assurance funded by Institute of Educational Development and Quality Assurance, Andalas University. On this occasion, we are grateful for the opportunity and fund that have been given to this research..

\section{References}

[1] Ramakrisnan $P$ et.al. Blended Learning: A Suitable Framework For E-Learning In HigherEducation, The $3^{\text {rd }}$ International Conference On e-Learning, Procedia Computer Science 67 (2012) page 513-526. (2011)

[2] Rusman. Model-model Pembelajaran,MengembangkanProfesionalismeGuru (in Bahasa).Jakarta: RajaGrafindo Perkasa. (2011)

[3] Thorne, K. Blended Learning: How to Integrate Online and Traditional Learning, USA: Kohan Page Limited.(2003)

[4] Bersin, J. The blended learning book: Best practices, proven methodologies, and lessons learned. San Francisco: Pfeiffer Publishing. (2004)

[5] Garrison, D. R. \& Kanuka, H. Blended learning: uncovering its transformative potential in higher education. Internet and Higher Education, Vol. 7, No. 2, pp. 95-105 (2004) 
[6] Mitchell, P. \& Forer, P. Blended learning: the perception of first-years geography student. Journal of Geography in Higher Education, Vol. 34, No. 1, pp. 77-89. (2010)

[7] Ginns, P. \& Ellis, R. A. Evaluating the quality of e-learning at the degree level in the student experience of blenden learning. British Journal of Educational Tecnology, Vol. 40,No. 4, pp. 652663 (2009)

[8] Graham, C. R. Blended learning system: definition, current trend, and future direction. Dalam C. J. Bonk \& C. R. Graham (eds), The handbook of blended learning; Global Perpectives, local designs. San Fransisco, CA; Pfeiffer, (2006)

[9] Dziuban C.D.Hartman, J.L. \& Moskal, P.D. Blendel Learning,Educause Center for Applied Research: Research BulletinVolume 7.(2004)

[10] Dwiyogo, W.D. PembelajaranBerbasis Blended Learning, SinergiAntaraPembelajaranTatapMuka, Offline dan Online (in Bahasa). Proceeding of Seminar Internasional Jurusan Teknologi Pendidikan Universitas Negeri Malang (2011). 